\title{
Informal Logic: An Overview
}

\author{
Ralph H. Johnson \& University of Windsor \\ J. ANThony Blair
}

\begin{abstract}
In this overview article, we first explain what we take informal logic to be, discussing misconceptions and distinguishing our conception of it from competing ones; second, we briefly catalogue recent informal logic research, under 14 headings; third, we suggest four broad areas of problems and questions for future research; fourth, we describe current scholarly resources for informal logic; fifth, we discuss three implications of informal logic for philosophy in particular, and take note of practical consequences of a more general sort.
\end{abstract}

Résumé: Notre article est un survol dans lequel nous présentons notre conception de la logique non formelle; exposons des idées erronées; distinguons notre conception de celles qui lui font concurrence; cataloguons en quatorze titres les recherches récentes en logique non formelle; suggèrons des problèmes à résoudre et des questions soulever dans quatre larges domaines de recherche pour l'avenir; identifions les resources courantes de la logique non formelle; décrivons ce qui se découle de la philosophie à cause de la logique non formelle; notons des conséquences pratiques et générales.

Keywords: informal logic, argument, argumentation theory, fallacy, fallacy theory, dialectics, rhetoric, deductivism, formalism, formal logic, argument schemes, argument analysis and evaluation, informal logic resources

\section{Introduction}

The issues we address in this paper are contained in the question that were put to the symposium on informal logic and philosophy at the World Congress of Philosophy at Boston in August 1998:

- What is the philosophical significance of informal logic?

- What are its applications/implications for other areas of philosophy?

In this overview we are not going to attempt to answer these questions in detail, though our views will become evident at the end of our agenda, which is as follows.

We begin with a brief statement about the nature of informal logic, what it is and what it is not. We then outline the problems and the issues informal logic addresses, followed by a brief account of the recent developments in the field, the resources available, and, finally, our view about its implications for philosophy. 
(We have added references to some of the work appearing since the World Congress.)

\section{Informal logic: what it is}

A. Towards a definition. Many have noted the strong Canadian presence in research in the field of informal logic. Perhaps coincidentally, both Canadians and informal logicians seem to be involved in an ongoing questioning about their identity. What is Canadian, as distinct from American, or British, French, and so on? Informal logicians find themselves asking: What is informal logic, as distinct from formal deductive logic, epistemology and critical thinking? Walton and Brinton (1997) say, in a recent anthology about the history of informal logic, that:

Informal logic has yet to come together as a clearly defined discipline, one organized around some well-defined and agreed upon systematic techniques that have a definite structure and can be decisively applied by users. (9)

This observation is significant, if irksome. For although there remain misconceptions about what informal logic is about, its leading practitioners (among whom we include Walton, Govier, and ourselves) more or less agree that its mandate is the study of norms of arguments (as contrasted with those of inference or implication). We propose once again (see Johnson and Blair 1987, 148) the following as a way to construe informal logic that fits with what both Govier (1987) and Walton (1989) have said:

Informal logic designates that branch of logic whose task is to develop non-formal ${ }_{2}$ standards, criteria, procedures for the analysis, interpretation, evaluation, critique and construction of argumentation in everyday discourse.

"Non-formal ${ }_{2}$ is borrowed from the Barth-Krabbe (1982) distinction of three different senses of 'form.' This logic is non-formal in the following respects. It does not rely on the chief analytic tool of formal deductive logic, the notion of logical form. Nor does it rely on the main evaluative function of formal deductive logic, validity. But that does not mean this logic is non-formal in the sense that it abandons reference to standards, criteria or procedures.

One problem with this definition, however, is that it limits informal logic to everyday discourse, a restriction that now seems to us both unnecessary and counterfactual. Historically informal logic's realm of interest has been what might be called natural-language argument, which has two sub-domains: (a) everyday discourse (discussions of public affairs, such as newspaper editorials) and (b) what Weinstein (1990) called "stylized"discourse, namely, the domain-specific styles of arguments, inference tickets and epistemologies of the special disciplines, such as the different sciences. The crucial divide is not between everyday and stylized discourses, but between artificial and natural languages. The latter is 
the focal point for informal logic (as distinct from formal deductive logic's focus on artificial languages and logistic systems), whatever the discourse.

B. Some misconceptions and competing conceptions of informal logic. We are going to run through an inventory of other responses to the question: "Just what is informal logic?" some of which anyone at all familiar with the research of the past 25 years will recognize as plainly wrong, and some of which are views of knowledgeable colleagues with which we disagree. We begin with what some consider a locus classicus - Ryle's (1954) statement, in which he uses the label 'informal logic' to refer to the implications of substantive concepts (such as time and pleasure), whose logic is "informal," as opposed to the logic of concepts such as conjunction and disjunction, whose logic is "formal." For Ryle, "informal logic" appears to be synonymous with "philosophical analysis." That is a much broader understanding than will be found in most of the work of informal logic's leading practitioners.

A second misconception of informal logic is that it is simply and exclusively the study of the informal fallacies (Carney and Sheer 1964, Kahane 1971). The study of informal fallacies does constitute a part, but only one part, of informal logic's subject matter.

A third misconception of informal logic is that it is formal logic without the formality. This idea is illustrated by the way that Copi produced his textbook, Informal Logic (1986), which consists simply of excerpts from his Introduction to Logic (1986) textbook, omitting the chapters covering formal logic. This view is wrong because, on the one hand, where formalism ${ }_{2}$ illuminates, informal logic employs it (see Woods and Walton, 1982); and on the other hand, the principal focus of informal logic is where formalism in that sense does not illuminate.

A point of disagreement within the field is the view that informal logic has the task of mediating between formal logic and reasoning in natural language. Such a view can be found in Goldman (1986) and Woods (1995). In our view, where deductive implications occur in natural language argumentation, they can be formalized (sometimes with profit, sometimes not). Implications that are not entailments, and other aspects of argument analysis and evaluation, are not amenable to such formal treatment.

A second view with which we disagree (which finds favour with such authors as McPeck (1981), Siegel (1988), and Weinstein (1994)) is that informal logic is applied epistemology in the sense that it is the application of epistemological findings to the evaluation of arguments. We might agree, but only if epistemology were stretched to include logic, dialectics and rhetoric.

Finally, we disagree with Fisher and Scriven (1997), who hold that informal logic is "the discipline which studies the practice of critical thinking and provides its intellectual spine" (76). Given our view that informal logic's defining subjectmatter is arguments and argumentation, and that critical thinking, in Fisher and Scriven's view, is "skilled and active interpretation and evaluation of observations 
and communications, information and argumentation" (21), we would assign to informal logic a narrower scope than they do.

\section{Recent Research}

In this section we look at some of the most recent areas of research in the field of informal logic.

1. The history of informal logic. One important development is the emergence of work on the history of informal logic. It has sometime been said that very little happened in informal logic between the time of Aristotle and the publication in 1970-71 of Hamblin's Fallacies (1970) and Kahane's Logic and Contemporary Rhetoric (1971). But Hansen and Pinto's anthology, Fallacies, Classical and Contemporary Readings (1995) includes several studies of historical treatments of the informal fallacies. And Walton and Brinton's Historical Foundations of Informal Logic (1997), with chapters on Isaac Watts, Whately, Bentham, Mill and Kant, shows how much applicable work did occur in the interstitial two millennia or so.

2. Argument as dialogue. A second area of research has been the modeling of arguments as dialogues of different kinds, carried out by Walton (1996) and Walton and Krabbe (1995). Their work might be seen as an elaboration of the pragmadialectical theory, with which it has close ties. It also informs their theory of fallacy. More recently, some limitations of the dialogue model have been suggested (Tindale 1996, Blair 1998).

3. Extending the concept of argument. Various scholars have been suggesting that the concept of argument be revised in other directions. Gilbert contends that argument is not exclusively verbal, but also emotional, visceral and "kisceral" (1997). Groarke (1996), Birdsell and Groarke (1996) and Blair (1996) include visual communications such as works of art as arguments. Most recently, Tindale (1999) argues for considering the rhetorical perspective as basic.

4. Reason and argument. At two levels, the relation of reason and argument has been explored in recent literature. At the micro level, reasoning and arguing have been distinguished and related (Pinto 1995, Blair 1999). At the macro level, the connection between argument and rationality has been explored-both the place of argument in rationality, and the constraints of rationality on argument (see Walton 1990, Finocchiaro 1992, Johnson 1996,).

5. New theory of inference. When someone adduces grounds in support of a claim, they may believe that the grounds deductively imply the claim, or they may believe that the grounds supply strong inductive support for the claim. Traditionally, these have been thought to be the only two possibilities for rational support for a claim. Citing Wellman and Wisdom, Govier (1987) has long contended that grounds may support a claim in other ways. Wellman (1971) used the term 'conduction' to parallel deduction and induction. Rescher (1976) used the term 'plausible reasoning' in a similar connection. More recently, Scriven (1987), using the term 'probative reasoning,' and Walton (1996b), using the term 'presumptive rea- 
soning,' have argued for such a third kind of evidentiary support. These authors are pointing in the direction of a new theory of inference.

6. Argument schemes. In the last several years the idea has emerged in the research of various scholars that argumentation schemes may hold the key to important problems in the theory of argument. Kienpointner (1992) has identified over 80 argument schemes, and classified them in an organizing typology. Walton (1996b) finds in argument schemes patterns of presumptive reasoning, and sees many fallacies as misused or abused argument schemes.

7. Structures and diagrams. A certain amount of attention in the literature has been devoted to the structure of arguments within argumentation, and to attendant models of argument diagramming. Freeman (1991) provided a Toulmin-inspired model crossed with a dialectical conception of argument, Snoeck Henkemans (1992) offered an analysis grounded in the pragma-dialectical approach, Walton (1996a) developed his own pragmatic, dialogue-based analysis.

8. Fallacy theory. The study of fallacy is closely associated with informal logic. Several important developments have taken place since Woods and Walton's (1989) classic series of papers on individual fallacies appeared in the 1970s and early 1980s. First, there is the fine recent collection of articles and research edited by Hansen and Pinto noted above: Fallacies: Classical and Contemporary Readings (1995). Second, Walton has proposed a kind of classification or hierarchy of mistakes (1995). Third, there has been a shift in the direction of seeing a fallacy as a certain kind of procedural or strategic mistake (Walton \& Krabbe 1995, van Eemeren \& Grootendorst 1992, Hintikka 1987). Fourth, we should mention Walton's continuing research on the fallacies. For the past decade, Walton has been producing a series of book length studies of the individual fallacies: to date he has published monographs on begging the question (1991), appeal to emotion (1992a), slippery slope (1992b), the argument from ignorance (1994), ad hominem (1998). In addition, besides numerous articles on individual fallacies, he has published two monographs on fallacy theory and fallacies in general $(1987,1995)$.

9. Premise adequacy. In distinction from the modern tradition of barring questions about the doxastic, epistemic or dialectical adequacy of premises of arguments from logic, informal logic's focus on argument evaluation has led its practitioners to consider the criteria of premise adequacy. There is quite widespread interest in the relevant-sufficient-acceptable triad first proposed by Johnson and Blair (1977). Among the authors who have embraced that doctrine (sometimes with slightly different terminology) are: Govier (1985) (who changes "sufficient" to "adequate"), Damer (1987), Freeman (1988), Little, Groarke and Tindale (1989), Barry (1992) and Seech (1992). Johnson and Blair (1994), Pinto and Blair (1993), and Freeman (1992) have argued for some norm of acceptability of premisses, a modification of van Eemeren and Grootendorst's model (1984). More recently, Blair (1995) has taken a relativistic position, while Johnson (1998) has insisted on truth as one criterion of premise adequacy. There have been numerous informal 
logic papers on relevance in the past decade (see, for examples, the papers by Tindale, Woods, Blair, Freeman, and Hitchcock in the special 1990 issue of $\mathrm{Argu}$ mentation on relevance). Sufficiency has received less attention (but see Blair 1991).

10. Developments in the theory of argument criticism. Walton (1995) argues that argument criticisms are not all of a piece, some are more serious than others; and that we must differentiate, for example, between weak execution and misuse or abuse. He also presents a possible typology of fallacy, distinguishing between a paralogism and sophism. In (1996) Johnson argues for a distinction between the evaluation of an argument and criticisms of an argument, and argues that we need to develop principles of argument criticism, among them: the principle of vulnerability, the principle of discrimination and the principle of logical neutrality. The latter have both been incorporated into Johnson and Blair's Logical Self-Defense (1994) but further discussion is needed as to how these are best formulated, how best justified, and whether there are other principles.

11. Investigation of argument's social role. In developing a theory of argument criticism, Johnson (1996) has been led to examine the role of argument as a social practice and to generate norms for the social obligations of arguers in both using the practice appropriately and in maintaining it in a healthy state. Govier (1987) and Walton (1990) also draw attention to the role of argument in the life of the society.

12. Impact of feminist theory. Feminist critical examination of the metaphors employed in the practice and the theory of argument have led to their revaluation (see Ayim 1988). The general concern raised about the privileging of the rational and the marginalization of the emotional have led to a debate among informal logicians about extending the conception of argumentation and about limiting the social role of argumentation (see Orr 1989, 1995, Nye 1990, Govier 1993, Menssen 1993, Gilbert 1994). Both Gilbert (1997) and Tindale (1999) devote sympathetic chapters to the influence of feminist insights on theory of argument.

13. Return to rhetoric. It is the burden of Tindale's Acts of Argument (1999) that a rhetorical perspective is both essential and fundamental for argument theory. Gilbert's Coalescent Argument also urges a turn toward a rhetorical perspective.

14. Argumentation as pragmatic. Walton has for some time been developing a pragmatic theory of argument (see, for example, Argument Structure: A Pragmatic Theory, 1995), and Johnson's recent book Manifest Rationality: A Pragmatic Theory of Argument (2000), presents a theory of argument that, while differing in many respects from Walton's, is similarly pragmatic.

\section{Problems and Questions for future research}

The recent theoretical developments just listed represent an ongoing research program for informal logic. To that extent, "problems and questions for future re- 
search" are constituted by the problems and questions stimulating current ongoing research. Still, a classification of the issues can be useful. In our view, there are four areas of "problematic" around which research in informal logic theory can be organized, all of which are clearly interrelated.

1. The theory of argument. How are argument and argumentation to be understood? Some, such as the proponents of the pragma-dialectic theory of the Amsterdam school (van Eemeren and Grootendorst 1984), hold that a general unified theory of argumentation is necessary to underwrite anything but ad hoc research in argumentation. Others believe useful work can be done on specific problems without working out a global theory of argumentation. The pragma-dialectical theory is one of the most comprehensive theories developed to date, although aspects of it have come under criticism (Blair and Johnson 1993, Woods 1994, Tindale 1996). If modifications are needed, what are they? Is some form of pragmadialectical theory the correct global theory of argumentation? If not, what is the alternative?

What logical types of argument are there? The old distinction between inductive and deductive arguments has been criticised as not being exhaustive (see "conductive," "probative," "presumptive" under item 5, above).

Several of the items of recent and ongoing research listed above fit comfortably within the "theory of argument" rubric: historical studies (item 1), relating dialogue to the dialectical nature of argument (item 2), stretching the concept argument (item 3 ), relating reason and argument (item 4 ), developing a new theory of inference (item 5), studying argument schemes (item 6) and working out the theoretical implications of certain insights of feminist theory (item 12).

2. The analysis of arguments. What is the correct way to analyze particular arguments? How is "correct" here to be parsed? It seems evident the question should be answered in terms of the purposes of such analysis, so these need to be identified. In the background are theories about the possible types of argument (which brings us back to the theory of argument); a corollary is a theory of how arguments may be diagrammed (see item 7, above). Should rhetorical (and other possibilities) as well as logical elements be kept track of, and if so, how is that best done? The rhetoric/logic distinction remains problematic still, so the problem of argument analysis raises it again.

Taking a broader perspective, however, identifies arguments as a type of discourse. Hence, theories of discourse analysis have a bearing on argument analysis. We here enter the cognate fields of pragmatics.

Clearly one's general theory of argument will be pertinent to issues of the analysis of arguments. If arguments are conceived as essentially dialogues between individuals, that will call for a different kind of analysis than if they are understood as addresses to general audiences. If arguments are to be identified as belonging to different schematic types, that too will affect how they are analyzed. So item 2 (argument as dialogue), item 3 (extending the concept of dialogue), item 
5 (new theory of inference) as well as item 7 (structures and diagrams) all fit under the rubric of argument analysis

3. The theory of evaluation. Here the initial motivating question is: What distinguishes a "good" arguments from a "bad" one? The reply will be: it depends on the perspective. The standard story is that an argument can be logically good, rhetorically good, or indeed good from a number of other possible perspectives. However, are these norms independent of one another? Some (e.g., Tindale 1992, 1996, 1999, Gilbert 1995) claim the need for a theory of evaluation that integrates different perspectives. Here too the issues of argument types and their related norms apply. Once argumentation is understood as a social, functional enterprise, pragmatics, social epistemology and communication theory in general (Willard 1983, 1989) would seem to have a bearing on its evaluation. Research into theories of fallacy, and into individual fallacies (item 8 above) and the close analysis of criteria of good argument (item 9 above) belong here as well.

4. The theory of criticism. We have long held out for a distinction between evaluation (identifying the criteria of good and bad) and criticism (the act of criticism, including the application of the criteria of good and bad argument, but also the public act of critique). The act of argument criticism presupposes a normative theory of the function of such criticism. Such a theory in turn presupposes a normative theory of the roles of argumentation. If argument is properly used to accomplish a set of aims, then the public critique of arguments will be related to their contribution to achieving those aims (see Walton 1990). Here is where we would situate item 10 (developments in the theory of argument criticism), item 11 (investigation of argument's social role) and item 12 (impact of feminist theory).

\section{Informal logic: Resources}

1. Journals. The journal Informal Logic has been the journal of record in the field since 1983, but articles on topics in or related to informal logic also appear regularly in Argumentation (founded 1986), Philosophy and Rhetoric, Argumentation and Advocacy (the journal of the American Forensic Association), and Inquiry: Critical Thinking Across the Disciplines (founded in 1988). Articles on informal logic topics have also appeared in a wide range of general philosophical journals including, but not at all restricted to, Synthese, Logique et Analyse and American Philosophical Quarterly.

2. Academic Programs. To our knowledge, there are no undergraduate or graduate programs devoted to informal logic. Virtually every college and university in the United States and Canada has an introductory-level course that teaches some informal logic (usually as part of either a "critical thinking" or "reasoning" orientation, or an introduction to logic course). We know of only a handful of upper-level undergraduate courses, and another handful of courses at the M.A. and Ph.D. levels, mostly in Canada. 
3. Conferences. The original conferences on informal logic were held at the University of Windsor (Windsor, Ontario) in 1978, 1983 and 1989. Conferences on both informal logic and critical thinking have been held at Sonoma State University (Rohnert Park, California) yearly since May, 1981 and at Christopher Newport University (Newport News, Virginia) each year from 1984 to 1988. Oakton Community College hosted five conference on critical think from 1988 to 1992 (Des Plains, Illinois), and a conference was held at George Mason University (Fairfax. Virginia) in 1995. The Association for Informal Logic and Critical Thinking has, since its inception in 1983, organized sessions on informal logic in conjunction with the Eastern, Central and Pacific meetings of the American Philosophical Association, and at some of the meetings of the Canadian Philosophical Association. Papers on informal logic have been on the program of the International Society for the Study of Argumentation conferences of 1986, 1990, 1994 and 1998 (University of Amsterdam, The Netherlands). Finally, the Ontario Society for the Study of Argumentation has held conferences devoted largely to informal logic in 1995, 1997 and 1999 (Brock University, Ontario).

4. Challenges. In our view, the field of informal logic faces two major, and related, practical challenges. It needs to find the support and resources to mount graduate level instruction, so that more young scholars become aware of its problematic and its literature, and make informal logic one area of concentration in their research programs. And it needs to penetrate the philosophical establishment, so that its theoretical findings become known and better reflected in undergraduate instruction.

\section{Implications for Philosophy}

What implications does informal logic have for philosophy, and indeed for the broader world we inhabit?

1. The end of deductivism. Philosophical reasoning and argument need informal logical analysis. It is a theoretical prejudice, not a fact, that the only respectable philosophical reasoning and argumentation employ deductive inferences. Ryle recognizes this when he says:

Whether a given philosophical argument is valid or fallacious is, in general, itself a debatable question. Simple inspection cannot decide. More often it is

a question of whether the argument has much, little or no force. $(1954,112)$

Perhaps the most important contribution of informal logic is that it helps to complete the revolution begun by the pragmatists who took issue with the classical (Platonic/Cartesian) theory of knowledge. Their work can be seen as an attempt to reconceptualize knowledge according to the model of the empirical sciences. Work in informal logic can be seen as an attempt to reconceptualize argumentation and free it from its historical attachment to what Toulmin and Perelman called the geometrical or mathematical model. This means, among other things, the end of deductivism - the idea that all implications are either deductive or defective; the 
end of the notion that argument should be conceived as proof; and the end of the class divisions between types of beliefs--elite beliefs being either necessary truths or truths that follow necessarily from premises known to be true, while secondbest are beliefs warranted by some probability calculus and all the rest are untouchable, not warranting acceptance by a reasonable person.

2. The demise of the view that logic is the theory of reasoning. By identifying reasoning with implication and taking the view that logic is essentially deductive logic, it was possible to believe that logic is in fact identical with the theory of reasoning. But once we adopt a broader view of logic and reasoning, it becomes clear that there is more involved in the construction of a theory of reasoning than formal deductive logic can provide (Finocchiaro 1984, Johnson 1996). If we are right, philosophical education needs to change its standard story about argument, reasoning, and logic.

Another implication of the work in informal logic has been to make it clear that logic is still developing. It does not carry this responsibility alone; other developments also attest to it, such as fuzzy logic (Zadeh 1975) and dynamic logic (van Benthem 1995). Yet, as mentioned, the vast body of philosophical education remains untouched by the findings of informal logic. As a consequence, serious mis-education continues.

3. The re-evaluation of formalism. Another result of informal logic has been to challenge the strong attachment to formalism and all that goes with it: algorithms, proof procedures, model theories, etc. Thus, it is not just the deductive bias inherent in traditional logic that informal logic has helped reveal; it is also the preference for formalism. This is what Toulmin is referring to when he says:

From the mid 17th century, Modern Philosophers regarded the formal issues

a central-not least, because they would be discussed in general,

"decontextual" terms. So, logic became equated with formal logic. $(1992,4)$

Here it is crucial to emphasize the point made earlier, that there are different senses of the term, 'formal' (see Barth \& Krabbe 1982, Johnson and Blair 1990). This realization opens the door to seeing that informal logic is not therefore a contraction or oxymoron, as some have alleged. We want to emphasize that informal logic is in no way incompatible with procedures, the application of criteria, or rigour. It is a question of which criteria, and here informal logic is informal because it rejects the logicist view that logical form (à la Russell) holds the key to understanding the structure of all arguments; and also the view that validity is an appropriate standard to demand of all arguments.

Another way of making this point is to say that informal logic is allied with the movement to make logic more empirical, less a prioristic (Barth 1992, Toulmin 1958, Weinstein 1990). 


\section{Broader practical implications}

Finally, it can be argued that the practice of argumentation has fallen on hard times in this culture. Serious observers have noted a decrease in literacy skills in the culture, the level of public debate seems at an all-time low, and public rhetoric is dominated by the confessional mode of television "talk-shows." Where in all this is the practice of argumentation to be cherished and nurtured, if not in the Academy? The teaching of high standards of argument interpretation, evaluation and critique that have practical application is the goal of the pedagogical side of informal logic.

Outside the Academy, in what some would call the "life-world," we have witnessed the withering away of the old world order. The post WWII coalitions existing under the threat of military force and power are now everywhere giving way to new alignments based on common interest and rational persuasion. The Balkan states, the mid-East, and parts of Africa, and the India-Pakistan sub-continent, are noteworthy exceptions. The human community must understand that the only force that we can expect to make use of is "the force of the better argument." Yet, paradoxically, it seems that just when there has never been a greater need for argumentation in the life-world, never has it been in greater danger as a cultural practice in the very societies premised on its healthy operation, the democratic societies. More than ever, we the philosophical community, and particularly those committed to the study of everyday argumentation, have something to contribute in educating the world.

Through its commitment to the development of better theories of argumentation, then, informal logic has an important service to render not merely to the theory of reasoning and to the academy, but also to the life-world.

\section{References}

Ayim, M. (1988) Violence and domination as metaphors in academic discourse. In T. Govier (ed.), Selected issues in logic and communication, 184-195. Belmont, CA: Wadsworth.

Barry, V. and Rudinow, J. (1992). Invitation to critical thinking. $2^{\text {nd }}$ ed. New York:

Barth, E. M. (1985). A new field: empirical logic/bioprograms, logemes and logics as institutions. Synthese 63: 376-388.

Barth, E.M. and Krabbe, E.C.W. (1982). From axiom to dialogue. A philosophical study of logics and argumentation. Berlin/New York: Walter de Gruyter.

Benthem, J. van. (1995). Logic and argumentation. In F.H. van Eemeren. R. Grootendorst, J.A. Blair and C.A. Willard (eds.), Proceedings of the third international conference on argumentation, Vol. 1,18-35. Amsterdam: SicSat.

Birdsell, D.S. and Groarke, L. (1996). Toward a theory of visual argument. Argumentation and Advocacy, 33.1, 110. 
Blair, J.A. (1991). What is the right amount of support for a conclusion? In F.H. van Eemeren. R. Grootendorst, J.A. Blair and C.A. Willard (eds.), Proceedings of the second international conference on argumentation, Vol. 1A, 330-337. Amsterdam: SicSat.

Blair, J.A. (1995). Premise adequacy. In F.H. van Eemeren. R. Grootendorst, J.A. Blair and C.A. Willard (eds.), Perspectives and approaches, Proceedings of the third ISSA conference on argumentation, Vol. I1, 191-202. Amsterdam: SicSat.

Blair, J.A. (1996). The possibility and actuality of visual arguments. Argumentation and Advocacy, 33.1, 23-39.

Blair, J.A. (1992). Premissary relevance. Argumentation 6.2, 203-217.

Blair, J.A. (1999). Walton's argument schemes for presumptive reasoning: A critique and development. In F.H. van Eemeren, R. Grootendorst, J.A. Blair and C.A. Willard (eds.), Proceedings of the fourth International Society for the Study of Argumentation conference. Amsterdam: SicSat.

Blair, J. A. and Johnson, R.H. (1987.) The current state of informal logic and critical thinking. Informal Logic 9, 147-151.

Blair, J.A. and Johnson, R.H. (1993). Dissent in fallacyland, Part I: Problems with van Eemeren and Grootendorst. In R.E. McKerrow (ed.), Argument and the Postmodern Challenge, Proceedings of the Eighth SCA/AFA Conference on Argumentation. Annandale, VA: Speech Communication Association.

Carney, J.D. and Sheer, R.K. (1964). Fundamentals of logic. New York: Macmillan.

Copi, I. (1986). Introduction to logic. $7^{\text {th }}$ ed. New York: Macmillan.

Copi, 1. (1986). Informal logic. New York: Macmillan.

Damer, T.E. (1987). Attacking faulty reasoning. $2^{\text {nd }}$ ed. Belmont, CA: Wadsworth.

Eemeren, F.H. van and Grootendorst, R. (1984). Speech acts in argumentative discussions. Dordrecht/Providence: Foris Publications.

Eemeren, F.H. van and Grootendorst, R. (1992). Argumentation, communication and fallacies: A pragma-dialectical perespective. Hillsdale, NJ: Lawrence Erlbaum Associates.

Finocchiaro, M. (1984.) Informal logic and the theory of reasoning. Informal Logic 6(2), 3-8.

Finocchiaro M. (1989.) Methodological problems in empirical logic. Communication and Cognition 22, 313-335.

Fisher, A. and Scriven, M. (1997). Critical thinking: It's definition and assessment. Point Reyes, CA: Edgepress.

Freeman, J.B. (1988) Thinking logically: Basic concepts for reasoning. Englewood Cliffs, NJ: Prentice-Hall.

Freeman, J.B. (1991). Dialectics and the macrostructure of argument: A theory of argument structure. Amsterdam: Mouton de Gruyter. Waveland Press.

Freeman, J.B. (1992). Relevance, Warrants, Backing, Inductive Support. Argumentation $6.2,219-235$.

Freeman, J.B. (1995). Premise acceptability, deontology, internalism, justification. Informal Logic 17.2, 270-278.

Gilbert, M.A. (1994). Feminism, argumentation and coalescence. Informal Logic 16.2, 95113. 
Gilbert, M.A. (1997). Coalescent argumentation. Mahwah, NJ: Lawrence Erlbaum Associates.

Goldman, A. (1986). Epistemology and cognition. Cambridge: MIT Press.

Govier, T. (1987). Problems in argument analysis and evaluation. Dordrecht: Foris Publications.

Govier, T. (1993). When logic meets politics: Testimony, distrust and rhetorical disadvantage. Informal Logic 15.2, 93-104.

Groarke, L. (1996). Logic, art and argument. Informal Logic 18.2\&3 (to appear).

Hamblin, C.L. (1970). Fallacies. London: Methuen.

Hansen, H.V. (1990). An informal logic bibliography. Informal Logic 12, 155-184.

Hansen, H.V. and Pinto, R.C. (Eds.). (1995). Fallacies: Classical and contemporary readings. University Park, PA: The Pennsylvania State University Press.

Hintikka, J. (1987.) The fallacy of fallacies. Argumentation 1, 211-238.

Hitchcock, D. (1992). Relevance. Argumentation 6.2, 251-270.

Johnson, R.H. (1996). The rise of informal logic. Newport News, VA: Vale Press.

Johnson, R.H. (2000). Manifest rationality: A pragmatic theory of argument. Mahwah, NJ: Lawrence Erlbaum Associates.

Johnson, R.H. and Blair, J.A. (1977). Logical self-defense. $3^{\text {rd }}$ ed., 1993. Toronto: McGrawHill Ryerson. U.S. ed., 1994. New York: McGraw-Hill.

Johnson, R. H. and Blair, J.A. (1991.) Contexts of informal reasoning : Commentary. In J.Voss, D. Perkins, and J.W. Segal, (eds.), Informal Reasoning and Education, Ch. 7, 131-150. Hillsdale, NJ: Lawrence Erlbaum Associates.

Kahane, H. (1971). Logic and contemporary rhetoric. Belmont, CA: Wadsworth.

Kienpointner, M. (1992). Alltagslogik: struktur und funktion von argumentationsmustern. Stuttgart-Bad Cannstatt: frommann-holzboog.

Little, J.F., Groarke, L.A. and Tindale, C.W. (1989). Good reasoning matters. Toronto: McLelland and Stewart.

McPeck, J. (1981). Critical thinking and education. New York: St. Martin's Press.

Menssen, S. (1993). Do women and men use different logics?: A reply to Carol Gilligan and Deborah Orr. Informal Logic 15.2, 123-138.

Nye, A. (1990). Words of power. New York: Routledge.

Orr, D. (1989). Just the facts Ma'am: Informal logic, gender and pedagogy. Informal Logic 11.1, 1-10.

Orr, D. (1995). On logic and moral voice. Informal Logic 17.3, 347-363.

Pinto, R.C. and Blair, J.A. (1993). Reasoning, A practical guide. Englewood Cliffs, NJ: Prentice-Hall.

Pinto, R.C. (1995). The relation of argument to inference. In F.H. van Eemeren. R. Grootendorst, J.A. Blair and C.A. Willard (eds.), Perspectives and approaches, Proceedings of the third ISSA conference on argumentation, Vol. 1, 271-286. Amsterdam: SicSat.

Rescher, N. (1976). Plausible reasoning: An introduction to the theory and practice of plausible inference. Assen: Van Gorcum 
Rescher, N. (1977). Dialectics: A Controversy-oriented approach to the theory of knowledge. Albany: State University of New York.

Ryle, G. (1954). Dilemmas. Cambridge: Cambridge University Press.

Scriven, M.(1987). Probative logic: Review and preview. In F.H. van Eemeren, R.

Grootendorst, J.A. Blair and C.A. Willard (eds.), Argumentation across the lines of discipline, 7-32. Dordrecht/Providence: Foris Publications.

Seech, Z. (1992). Logic in everyday life: Practical reasoning skills. $2^{\text {nd }}$ ed. Belmont, CA: Wadsworth.

Siegel, H. (1988). Educating reason: Rationality, critical thinking and education. New York: Routledge.

Snoeck Henkemans, A.F. (1992). Analysing complex argumentation. Amsterdam, SicSat. Tindale, C.W. (1992). Audiences, relevance and cognitive environments. Argumentation $6.2,177-188$.

Tindale, C.W. (1996). Fallacies in transition: An assessment of the pragma-dialectical perspective. Informal Logic 18.1, 17-33.

Tindale, C.W. (1999) Acts of arguing: A rhetorical model of argument. Albany: State University of New York Press.

Toulmin, S.E. (1958). The uses of argument. Cambridge: Cambridge University Press.

Toulmin, S.E. (1992). Logic, thetoric \& reason: redressing the balance. In F.H. van Eemeren.

R. Grootendorst, J.A. Blair and C.A. Willard (eds.), Argumentation illuminated, 311. Amsterdam: SicSat.

Walton, D. (1987). Informal fallacies: Towards a theory of argument criticisms. Amsterdam: John Benjamins.

Walton, D. (1989). Informal logic: A handbook for critical argumentation. Cambridge: Cambridge University Press.

Walton, D. (1991). Begging the question. Westport, CT: Greenwood.

Walton, D. (1992a). The place of emotion in argument. University Park, PA: The Pennsylvania State University Press.

Walton, D. (1992b). Slippery slope arguments. Oxford: Oxford University Press.

Walton, D. (1994). Arguments from ignorance. University Park, PA: The Pennsylvania State University Press.

Walton, D. (1995a). A pragmatic theory of fallacy. Tuscaloosa and London: The University of Alabama Press.

Walton, D. (1996a). Argument structure: A pragmatic theory. Toronto: University of Toronto Press.

Walton, D. (1996b). Argumentation schemes for presumptive reasoning. Mahwah, $\mathrm{NJ}$ : Lawrence Erlbaum Associates.

Walton, D. (1998). Ad hominem arguments. Tuscaloosa, Alabama: University of Alabama Press.

Walton, D. and Brinton, A. (Eds.). (1997). Historical foundations of informal logic. Aldershot: Ashgate.

Weinstein, M. (1990). Towards a research agenda for informal logic and critical thinking. Informal Logic 12, 121-143. 
Weinstein, M. (1994). Informal logic and applied epistemology. In R.H. Johnson and J.A. Blair (eds.), New essays in informal logic, 140-161. Windsor: Informal Logic.

Wellman, C. (1971). Challenge and response, justification in ethics. Carbondale and Edwardsville, IL: Southern Illinois University Press. London and Amsterdam: Feffer \& Simons, Inc.

Willard, C.A. (1983). Argumentation and the social grounds of knowledge. Tuscaloosa: The University of Alabama Press.

Willard, C.A. (1989). A theory of argumentation. Tuscaloosa: The University of Alabama Press.

Woods, J. (1992). Apocalyptic relevance. Argumentation 6.2, 189-202.

Woods, J. (1994). Is the theoretical unity of the fallacies possible? Informal Logic 16.2, $77-85$.

Woods, J. (1995). Fearful symmetry. In H.V. Hansen and R.C. Pinto (eds.), Fallacies: Classical and contemporary readings. University Park, PA: The Pennsylvania State University Press.

Woods, J. and Walton, D. (1982). Argument, the logic of the fallacies. Toronto: McGrawHill Ryerson.

Woods, J. and Walton, D. (1989). Fallacies: Selected papers, 1972-1982. Dordrecht/ Providence: Foris Publications.

Zadeh, Lotfi. (1975.) Fuzzy logic and approximate reasoning. Synthese, 30: 407-428.

Ralph H. Johnson and J. Anthony Blair Department of History, Philosophy \& Political Science University of Winds or Windsor, Ontario Canada N9B $3 P 4$

johnsoa@uwindsor.ca tblair@uwindsor.ca 